\title{
Spatio-temporal variation in recruitment on a seasonal, tropical rocky shore: the importance of local versus non-local processes
}

\author{
Neil Hutchinson, Gray A. Williams* \\ Department of Ecology \& Biodiversity and the Swire Institute of Marine Science, The University of Hong Kong, \\ Pokfulam Road, Hong Kong
}

\begin{abstract}
The impacts of grazing and recruitment patterns on intertidal assemblage structure were examined on a semi-exposed rocky shore in Hong Kong. Recruitment was monitored in plots arranged in 3 different sites on the shore, in which fence treatments were used to manipulate grazer access. Plots were colonised by a variety of sessile invertebrates, erect and encrusting algae throughout the study period, with different species recruiting to sites 10 s of metres apart during the same time period. Recruitment was highest during the winter with erect and encrusting algae colonising free space in all plots. While full fences around plots led to a higher percentage cover of algae, cover in partially fenced and open plots fluctuated at different times and between sites. Free space availability was greatest during summer, due to the seasonal die-off of species and negligible recruitment, as new species were unable to survive the extreme physical conditions during this period. The role of the local process of grazing, therefore, appeared to be of secondary importance in structuring assemblages on Hong Kong shores compared to non-local processes such as recruit supply and seasonal variation in physical stress.
\end{abstract}

KEY WORDS: Hong Kong · Tropical rocky shores $\cdot$ Recruitment $\cdot$ Herbivory $\cdot$ Settlement $\cdot$ Nested design $\cdot$ Spatial variation $\cdot$ Temporal variation

\section{INTRODUCTION}

A fundamental process shaping community structure in most habitats is the influence played both spatially and temporally by the arrival and subsequent survival of new individuals (Connell 1985). This initial process is responsible for the supply of individuals to existing assemblages as well as the re-colonisation of denuded areas or newly created space (Lubchenco \& Menge 1978, Sousa 1984). In the marine environment, therefore, due to the effect of mixing in the plankton, supply side ecology (Underwood \& Fairweather 1989) usually functions on a large, non-local scale in the shaping of intertidal communities.

Numerous physical and biological factors play important roles in the arrival and subsequent survival of

*Corresponding author: E-mail: hrsbwga@hkucc.hku.hk recruits in intertidal assemblages. These include processes that act at a limited local scale, such as the impact of benthic grazers and predators (Hawkins \& Hartnoll 1983, Menge \& Sutherland 1987), substrate type and complexity (Raimondi 1988), and the availability of free space (Pierron \& Huang 1926, Paine \& Levin 1981) and non-local processes including oceanic currents (Crisp 1974, Roughgarden et al. 1987) and changes in climatic conditions (Barry et al. 1995). Whilst spatial and temporal distribution patterns of organisms are governed to a certain extent by these external factors (Hoffmann \& Ugarte 1985, Roughgarden et al. 1987), the availability of recruits at the time when suitable conditions exist for their settlement and survival is paramount (Sousa 1984).

Recently, researchers have realised the importance of examining processes at varying spatial scales in an attempt to determine their generality and to what 
extent these processes vary from previous localised models (Underwood \& Denley 1984, Underwood \& Petraitis 1993). Little work, for example, has been conducted on medium (e.g. 10s of m) to small scale ( $\mathrm{cm}$ to $\mathrm{m}$ ) spatial variation in arrival and survival of species on intertidal rocky shores (Sousa 1984, Camus \& Lagos 1996), and studies have tended to concentrate on differences between shores rather than variation within shores (Underwood 1993, 1994). Studies have shown recruitment to be spatially and temporally variable (Sousa 1984, Jernakoff 1985), and sites in close proximity, which one would expect to receive the same potential pool of recruits (Johnson \& Black 1984), can have very different settlement patterns (Hawkins \& Hartnoll 1982, Johnson \& Black 1982). Reasons for differences in settlement at this scale may include variation in potential recruit densities in the water column, coupled with other aspects such as localised, smallscale variation in grazer densities on the shore resulting in an interaction between local and non-local processes (Underwood \& Jernakoff 1984). These smaller scale patterns of recruitment have largely been overlooked (see discussion by Roughgarden et al. 1987), and their contribution to spatial variation in established systems is seldom appreciated. In open systems, therefore, processes usually thought of as shaping assemblages at a large scale, such as recruit transport in water currents (Johnson \& Black 1998), may be responsible for medium scales of spatial variation within shores, rather than on-shore local processes to which such differences are usually attributed (Gaines \& Roughgarden 1985).

There have been relatively few studies of settlement and recruitment of sessile species in tropical regions (Lawson 1957), with studies on algal (Machado et al. 1992, Williams 1993b, Kaehler \& Williams 1997) and invertebrate (Sutherland \& Ortega 1986, Sutherland 1987, Williams 1994, Walters et al. 1996) recruitment concentrating on particular factors influencing recruitment (e.g. substrate inclination and shading effects), with little regard to changes in patterns of recruitment over a variety of spatial scales (but see Sutherland 1987). Settlement and recruitment of sessile species have been shown to vary seasonally on Hong Kong rocky shores (Hodgkiss 1984, Williams 1993b, Kaehler \& Williams 1996). Survival of recruits during summer is low, due in some part to increased levels of physical stress (Williams 1993b, Kaehler \& Williams 1996). Previous studies have shown that recruitment is variable and affected by differences in various physical and biological factors (Kaehler \& Williams 1996, 1997) at broad scales (e.g. tidal height). Little is known, however, about patterns of recruit survival over medium spatial scales at the same height and to what extent variation in initial settle- ment patterns and biological processes, such as grazing, affects the distribution of recruits. The present study is particularly concerned with how important such local-scale impacts are in influencing recruitment that may be spatially variable due to larger scale, non-local processes.

\section{MATERIALS AND METHODS}

Study site. Experiments were conducted on a semiexposed stretch of shore at Cape d'Aguilar, Hong Kong $\left(22^{\circ} 13^{\prime} \mathrm{N}, 114^{\circ} 12^{\prime} \mathrm{E}\right)$. Three sites within 10 s of metres of each other $(A, B, C)$ were chosen, with similar species compositions, substrate angle $\left(0\right.$ to $\left.30^{\circ}\right)$ and aspect at $1.5 \mathrm{~m}$ above chart datum (CD).

Exclusion plots. A nested experimental design was used to examine spatial and temporal variation in recruitment of sessile species at the 3 sites (A to C) either with or without grazer access. To manipulate grazer access, 3 treatments were used: unfenced (U) plots, fenced (F) plots (to exclude molluscan grazers) and partially fenced (P) plots (L-shaped fences at 2 opposite corners of the plots, as a control for potential fence effects). A fence with an out-turned lip was used to exclude mobile molluscs larger than the mesh size of $5 \times 5 \mathrm{~mm} ; 22 \times 22 \mathrm{~cm}$ wire fences (allowing a $1 \mathrm{~cm}$ boundary to control for edge effects and, therefore, a $20 \times 20 \mathrm{~cm}$ experimental area in the centre) were employed. At each of the sites, 15 plots were created and 5 replicates of each treatment were randomly assigned between the plots.

Plots were scraped with a metal blade to remove organisms already present, and blowtorched until whitehot to sterilise. Treatments were then established, and plots were left for $1 \mathrm{mo}$, during which time they were visited on a regular basis (every 3 to $5 \mathrm{~d}$ ) to maintain and monitor the effectiveness of the fences against grazers. Only on rare occasions were grazers found within plots, necessitating removal. After $1 \mathrm{mo}$, sessile species in each plot were identified and their percentage cover was recorded using a 100-point, doublestrung, $20 \times 20 \mathrm{~cm}$ quadrat.

Sites were re-visited on the day after scoring, fences were removed, and all plots were re-scraped and reburned. After this process, treatments were once again randomly allocated to the plots. This procedure resulted in sterile plots being created and left for 1 lunar month, sampled, and then re-sterilised. Plot preparation and scoring was repeated for 14 mo from September 1997 to October 1998, including the 2 distinct Hong Kong seasons (the hot, wet summer from May to September $\left(\sim 25\right.$ to $\left.29^{\circ} \mathrm{C}\right)$ and the cool, dry winter from November to March $\left(\sim 15\right.$ to $\left.18^{\circ} \mathrm{C}\right)$; see Kaehler \& Williams 1996). 
Chlorophyll a variation. To analyse variation in chlorophyll a concentration, rock chips $\left(\sim 3 \mathrm{~cm}^{2}\right)$ were collected from each plot after each month, and also after blowtorching. Rock chips were rinsed in seawater and transported to the laboratory damp, where chlorophyll a was estimated within $24 \mathrm{~h}$ of collection by cold methanol extraction (see Nagarkar \& Williams 1997).

Transect surveys. On a monthly basis, the percentage cover of sessile species and abundance of mobile herbivorous molluscs at each site were determined to examine possible differences in grazer pressure between the 3 areas. Surveys were conducted within the same week as monthly plot manipulations, by randomly placing ten 100-point, double-strung, $50 \times 50 \mathrm{~cm}$ quadrats along a $10 \mathrm{~m}$ transect at $1.5 \mathrm{~m} \mathrm{CD}$ at each site.

Data analysis. Spatial and temporal variation in recruitment was analysed using mixed-model ANOVA to determine differences between and within sites and treatments (Morrisey et al. 1992, Underwood 1997). A 4 factor model was used to examine variation in cover of broad species groupings (defined in Tables 1 \& 2) and chlorophyll a concentration with season (2 levels, i.e., winter and summer; orthogonal and fixed [winter = November to March; see Kaehler \& Williams 1996; summer = May to September]), date (4 levels; random and nested within season), site (3 levels; random and orthogonal) and treatment (3 levels; fixed and orthogonal). For comparison of herbivore abundance between the transects at Sites A to C, a 3-factor model was used to examine variation with season (2 levels; orthogonal and fixed), date (4 levels; random and nested within season) and site (3 levels; orthogonal and random).
As the same plots were used on a monthly basis, plots were re-burned and treatments randomly re-allocated among plots every month in an attempt to reduce potential problems of non-independence. In cases where there are significant interactions between random and fixed factors in the model, it is not appropriate to examine these differences with multiple-comparison tests (Underwood 1997). It was, however, possible to visualise treatment differences using non-parametric multivariate techniques. Bray-Curtis similarities were calculated for fourth-root-transformed data in order to give ordinations that were relevant for the most abundant species. Two-factor, crossed ANOSIM (Clarke 1993) was performed on separate dates using similarity data to determine differences between sites (using the means of treatments) and treatments (using the means of the sites). Non-metric multidimensional scaling (nMDS) ordinations were produced for 4 dates in winter and summer to reveal whether similarities in assemblage structure between dates varied with season. For nMDS ordinations, stress levels should ideally be $<0.1$, but values $<0.2$ are thought to still give an adequate representation of relationships between replicates (see Clarke 1993). The significance of $R$ values from ANOSIM reflect differences in assemblage structure in experimental plots among sites and among treatments and are shown graphically (see Fig. 5) in order to indicate how this varied on a monthly basis. More in-depth analyses of data were required to reveal differences in grazer-treatment effects within each separate site, and these were performed using 1-way ANOSIM on each sampling date, for each site.

Table 1. Allocated groupings of sessile species found on semi-exposed shores in Hong Kong

\begin{tabular}{|lll|}
\hline Encrusting algae & Erect algae & Sessile invertebrates \\
\hline Ralfsia expansa & Endarachne binghamiae & Tetraclita spp. \\
Hapalospongidion gelatinosum & Enteromorpha spp. & Capitulum mitella \\
Endopleura aurea & Porphyra suborbiculata & Balanus spp. \\
Hildenbrandia rubra & Ulva spp. & Spirorbids \\
Hildenbrandia occidentalis & Dermonema frappieri & \\
Coralline algae & Ectocarpus sp. & \\
& Hinksia mitchelliae & \\
\hline
\end{tabular}

Table 2. Allocated groupings of molluscan grazer species found on semi-exposed shores in Hong Kong

\begin{tabular}{|llll|}
\hline Chitons & Limpets & Coiled gastropods & Littorinids \\
\hline Acanthopleura japonica & Cellana grata & Nerita albicilla & Nodilittorina radiata \\
& Cellana toreuma & Monodonta labio & Nodilittorina vidua \\
& Patelloida pygmea & Planaxis sulcatus & \\
& Patelloida saccharina & Chlorostoma argyrostoma & \\
& Siphonaria spp. & Lunella coronata & \\
& Siphonaria japonica & & \\
& & \\
\end{tabular}




\section{RESULTS}

Recruitment patterns varied broadly throughout the sites in winter and summer, with the greatest percentage cover of recruits occurring from November 1997 to March 1998 (Fig. 1). Site A had the greatest range of organisms recruiting to plots, including sessile invertebrates, coralline algae, erect and encrusting algae. In contrast, recruitment at Sites B and C was predominantly by erect and encrusting algal species (Fig. 1), with few sessile invertebrates.

\section{Site differences}

Sessile invertebrates

Balanus spp. (predominantly B. amphitrite), Tetraclita spp. (predominantly T. japonica) and spirorbids recruited sparsely to plots at each of the sites. Percentage cover in plots varied between sites, with $B$. amphitrite occurring predominantly in plots at Site A and spirorbids in plots at Sites B and C. Recruitment of $B$. amphitrite occurred in November/December in grazer exclusions (fenced plots) at Site A ( 5\% \pm 7 ; mean $\pm \mathrm{SD})$, whereas recruitment of spirorbids occurred in November at Site B $(\sim 8 \% \pm 16)$ and year-round, but at lower levels $(\sim 2 \% \pm 2)$ at Site C. The overall percentage cover of sessile species recruits was greatest in fenced and partially fenced plots in all sites and least in unfenced plots throughout the study (Fig. 1). Sessile invertebrate cover on un-manipulated stretches of shore within sites sampled on the transects was rare, with sessile invertebrates recruiting predominantly on cleaned rock surfaces in manipulated plots.

\section{Erect algae}

The abundance of erect algae found in winter 1997 varied considerably among the sites (Fig. 1). While the highest percentage cover occurred mainly in fenced plots and least in unfenced plots, cover in partially fenced plots varied considerably on a monthly basis
SITE A
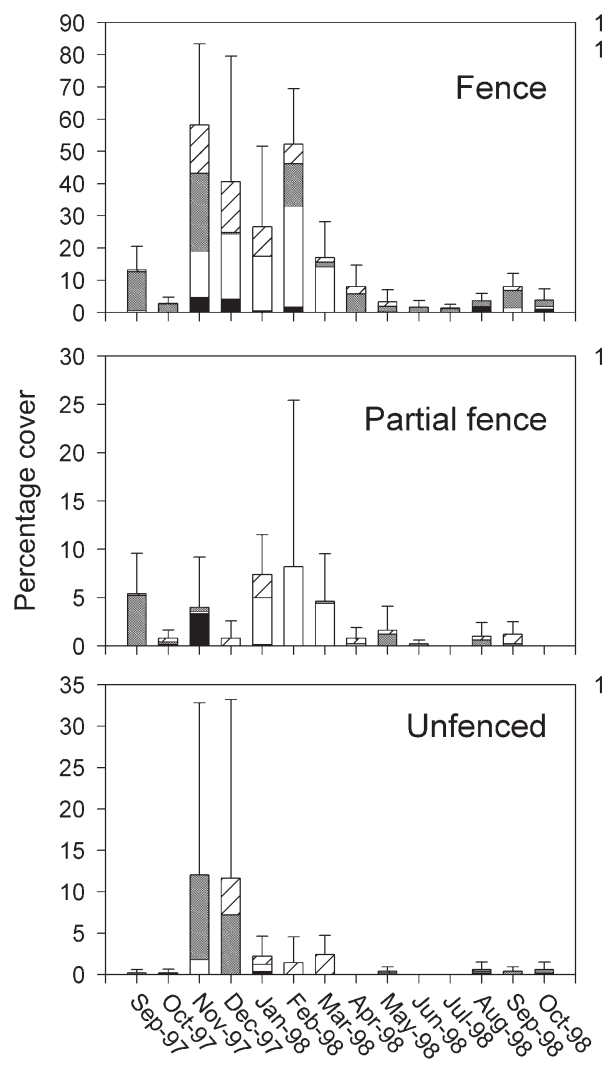

Sampling times
SITE B
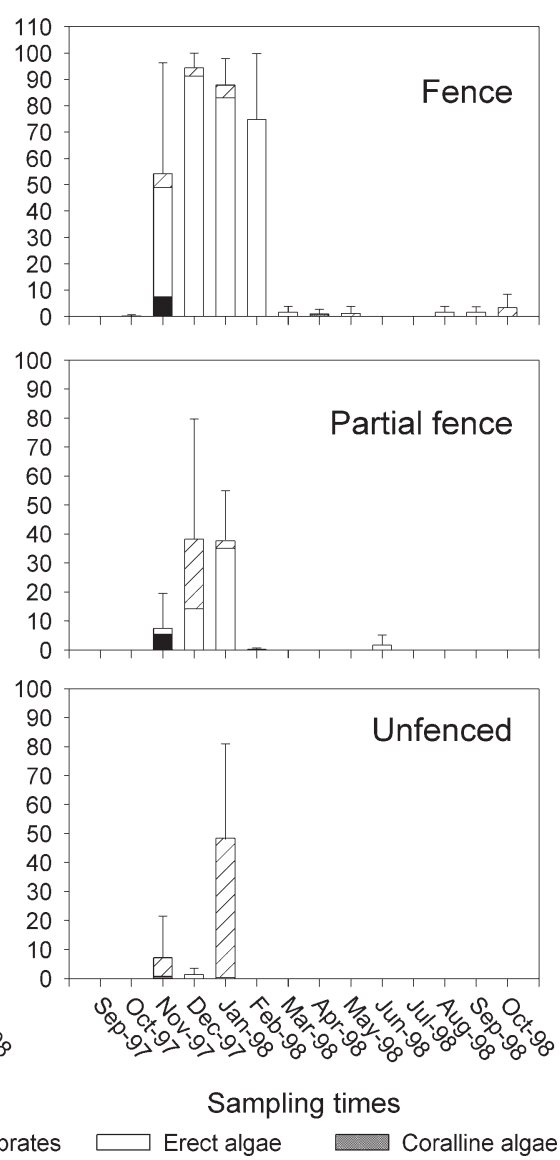

SITE C
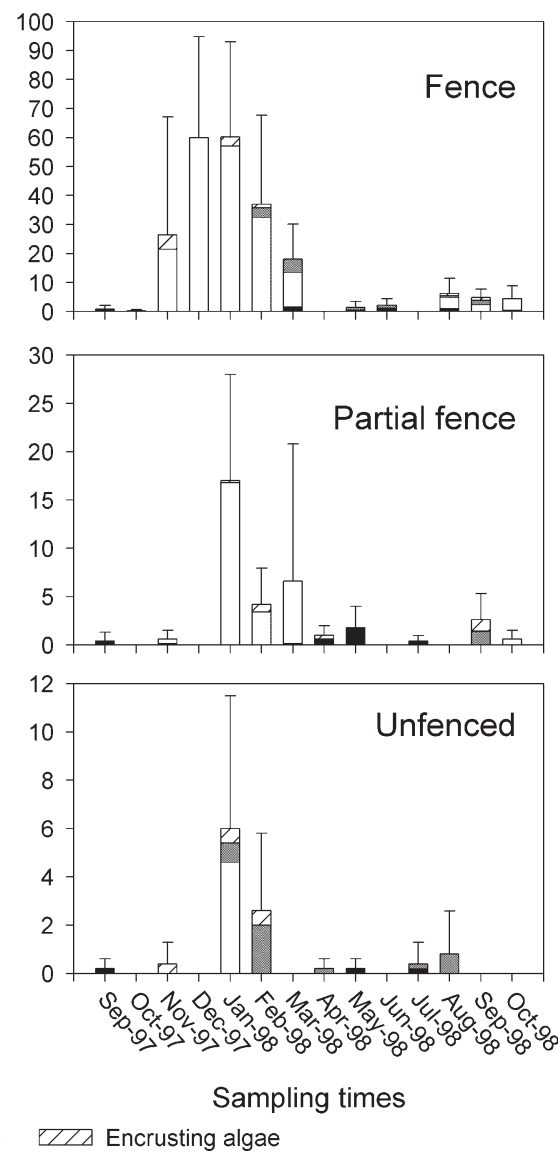

Fig. 1. Mean (+ SD) variation in sessile species recruitment in experimental plots created on a monthly basis at Sites A to $\mathrm{C}(\mathrm{n}=5)$. Note scale changes 
and often at levels more similar to the fenced than unfenced plots. Site A had the highest number of species in winter 1997, with peaks of Endarachne binghamiae in February $(\sim 12 \% \pm 10$; mean $\pm \mathrm{SD})$, green sporelings in December (a mixed group containing Enteromorpha sp. and assorted green algal sporelings; $\sim 10 \% \pm 20$ ), Hinksia mitchelliae in February $(\sim 7 \% \pm 9)$, Porphyra suborbiculata in December to March ( 10\% \pm 12$)$, and Ulva spp. in January $(\sim 11 \% \pm 7)$ all recruiting to fenced plots. In contrast, $H$. mitchelliae did not occur in plots at either Sites B or C during the study, and there was no recruitment of Endarachne binghamiae at Site $\mathrm{C}$ and only 1 occurrence of this species in February at Site B $(\sim 70 \% \pm 25)$. Plots at Site B were predominantly colonised by $P$. suborbiculata, and those at Site $\mathrm{C}$ by a mixed turf of green sporelings. As was seen for un-manipulated areas on transects, there was no recruitment of erect algae during summer in unfenced plots and only very sparse recruitment, on rare occasions, in fenced and partially fenced treatments $(<1 \%)$. The same species were found on the transects, except that mixed green sporelings were only briefly recorded in August on Transect A. The percentage cover of erect algae in plots was consistently higher than on transects at the sites (generally $<10 \%$ cover on transects), although there was a dramatic peak in cover of P. suborbiculata at Site B during January 1998, which covered almost $80 \%$ of the rock surface and was the highest total cover found at any site.

\section{Encrusting algae}

Recruitment of encrusting algae at Sites A to C varied considerably between months, peaking from November 1997 to February 1998 (Fig. 1). Cover of the red alga Hildenbrandia rubra was greatest in November at Site A $(\sim 15 \% \pm 10$; mean $\pm \mathrm{SD})$, and in December and January at Sites B and C ( 5\% \pm 8). Other encrusting species recruiting in plots at Site A included coralline species that peaked in cover in November and December (Fig. 1), and the brown alga Ralfsia expansa $(\sim 5 \% \pm 4)$ as well as rare occurrences $(<5 \%$ cover) of Hapalospongidion gelatinosum, Endopleura aurea and Hildenbrandia occidentalis. At Site B, $R$. expansa peaked in cover from November to January in fenced plots $(\sim 5 \% 6)$, in December in partially fenced $(\sim 20 \% \pm 40)$ plots, and in January in unfenced plots $(\sim 50 \% \pm 30)$. Cover of Hildenbrandia rubra and $R$. expansa at Site $\mathrm{C}$ was low $(<5 \%)$, whereas cover of coralline spp. peaked in February $(\sim 13 \% \pm 6)$. On transects at Sites A and C, the percentage cover of encrusting species was generally low $(<3 \%)$. A greater variety of species was found on the transects than in the plots at each site; however, the species complements on transects included all those found in experimental plots. Cover of $H$. rubra was consistently high ( 15 to $30 \%$ ) on Transect B from October to May, before dropping during summer 1998, after which it was reduced to low levels similar to those of other species. There was considerable patchiness in plots and transects (high standard deviations: Fig. 1).

\section{Spatial variation in grazer exclusion}

There were significant differences in the percentage cover of coralline algae and sessile invertebrates in experimental plots during the study, with interactions between site, treatment and time (Table 3). The percentage cover of recruits of erect and encrusting algae in plots also varied significantly, with interactions between site $\times$ date (time) as well as treatment $\times$ date (Table 3). In contrast, for chlorophyll a concentration there were no significant interactions between factors, but there was significant variation with date and with site (Table 3, Fig. 2). Although further differences
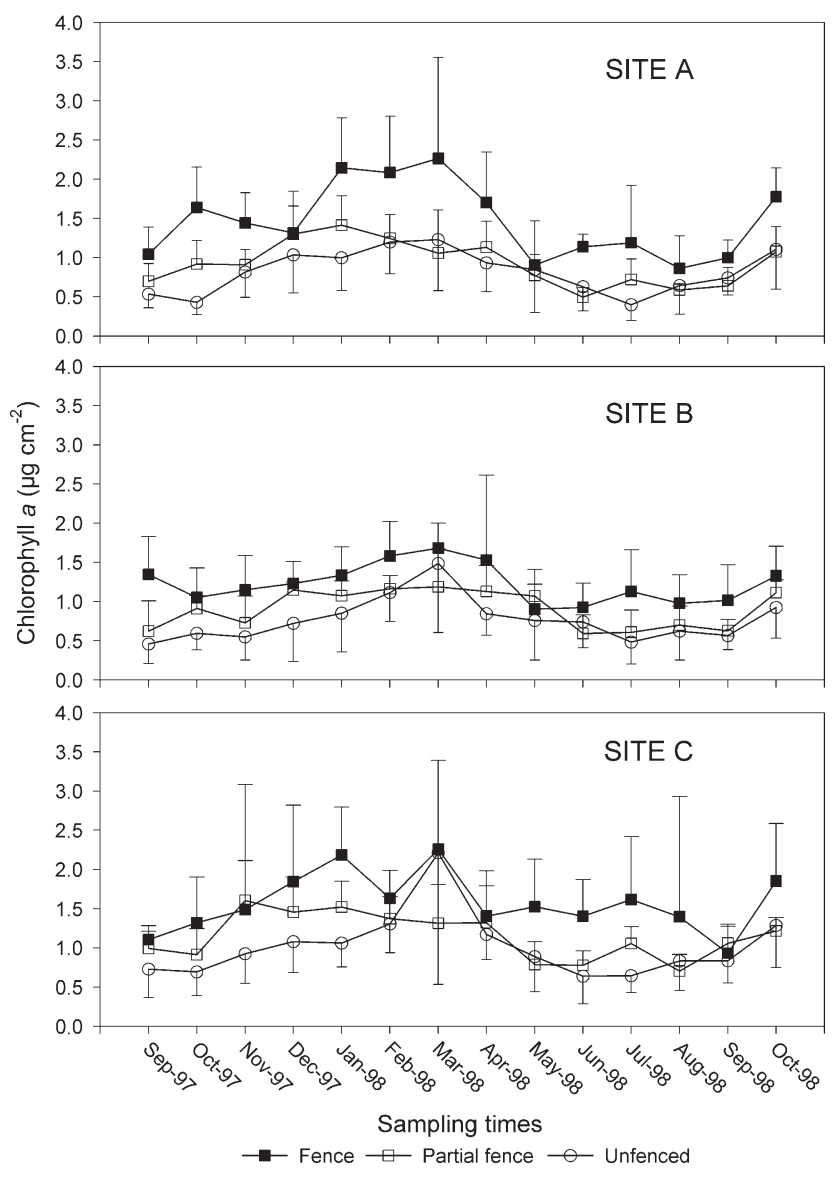

Fig. 2. Mean $( \pm \mathrm{SD})$ variation in chlorophyll a concentration for all experimental plots created on a monthly basis at Sites A to $C(n=5)$ 


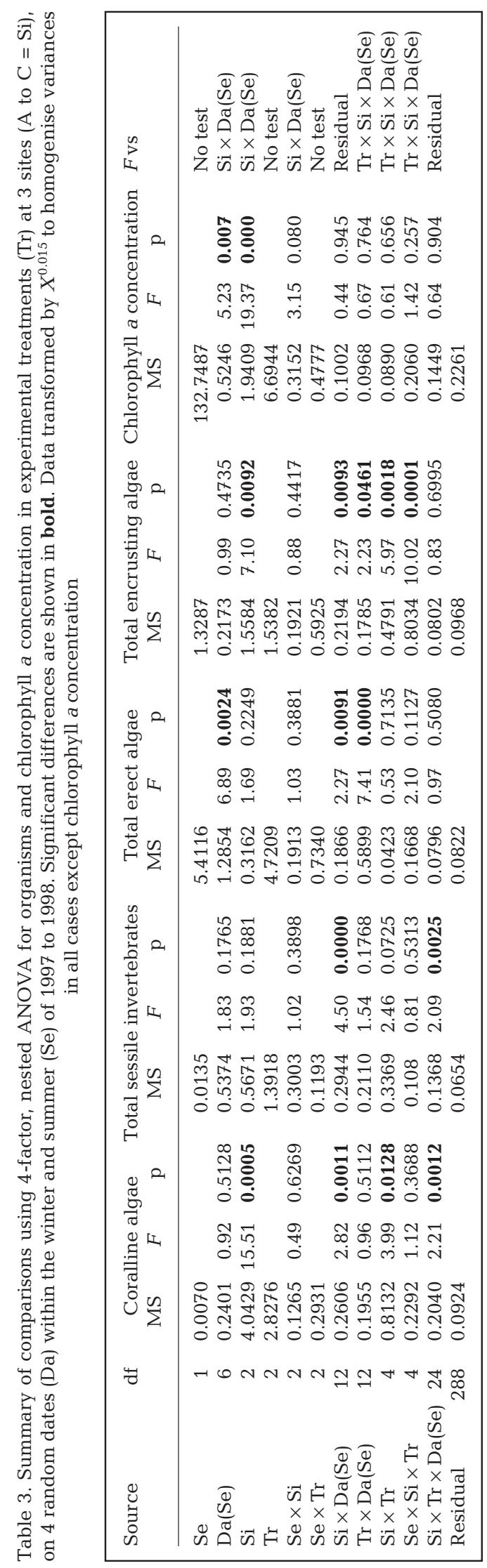

between treatments were not testable and pooling procedures could not be used on this data set (Underwood 1997), there did, however, appear to be patterns between treatments with generally higher values in fenced plots (grazer exclusions) than in the other treatments (Fig. 2). While the total abundance of grazers differed significantly between sites (Table 4), with the highest abundances at Site A (Fig. 3), there were no obvious patterns in percentage cover of algae (Fig. 1) and chlorophyll a concentration (Fig. 2) in plots at different sites associated with this variation.

Table 4. Comparison using 3-factor, nested ANOVA of total grazer abundance on 3 transects (Sites A to C), on 4 random dates within the winter and summer of 1997 to 1998. Significant differences are shown in bold. Se: season; Da: date; Si: site

\begin{tabular}{|lrrrcl|}
\hline Source & df & MS & \multicolumn{1}{c|}{$F$} & p & $F$ vs \\
\hline Se & 1 & 80.5042 & & & No test \\
$\mathrm{Da}(\mathrm{Se})$ & 6 & 14.1542 & 0.70 & 0.6556 & $\mathrm{Si} \times \mathrm{Da}(\mathrm{Se})$ \\
$\mathrm{Si}$ & 2 & 497.7375 & 24.60 & $\mathbf{0 . 0 0 0 1}$ & $\mathrm{Si} \times \mathrm{Da}(\mathrm{Se})$ \\
$\mathrm{Se} \times \mathrm{Si}$ & 2 & 48.9542 & 2.42 & 0.1309 & $\mathrm{Si} \times \mathrm{Da}(\mathrm{Se})$ \\
$\mathrm{Si} \times \mathrm{Da}(\mathrm{Se})$ & 12 & 20.2292 & 1.07 & 0.3864 & Residual \\
Residual & 216 & 18.8977 & & & \\
\hline
\end{tabular}
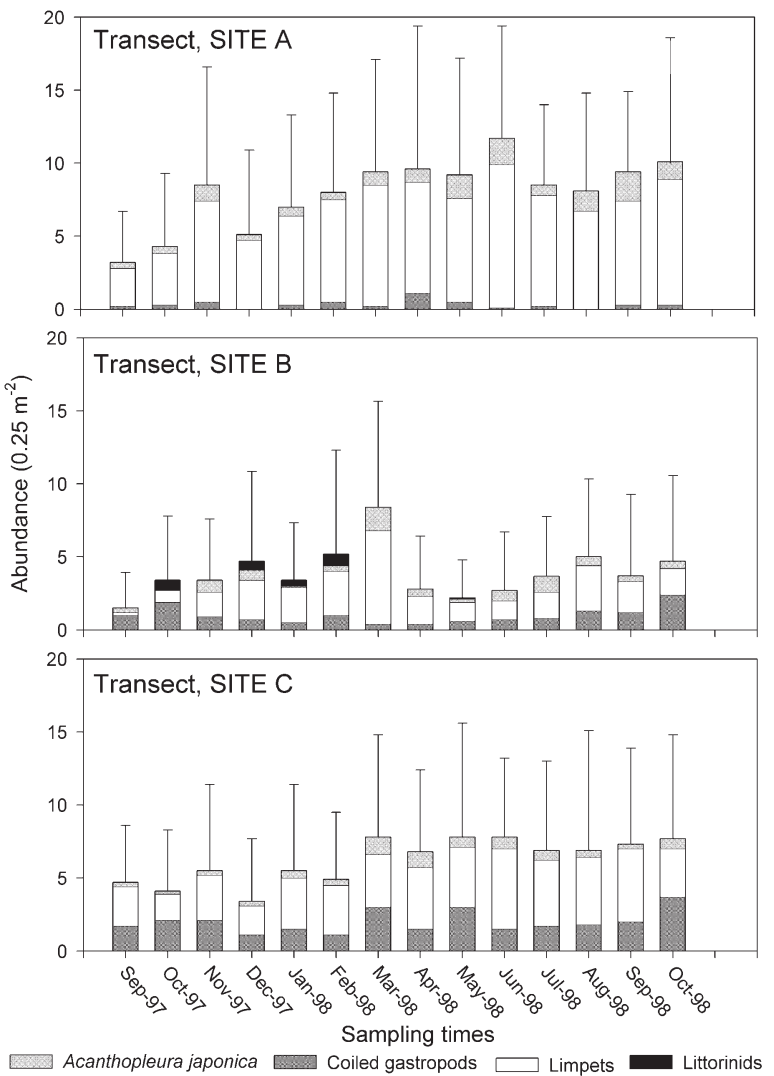

Fig. 3. Mean (+ SD) abundance of molluscan grazer groups on the 3 transects (Sites A to C) $(n=10)$. See Table 2 for details of species groups 


\section{WINTER 1997}
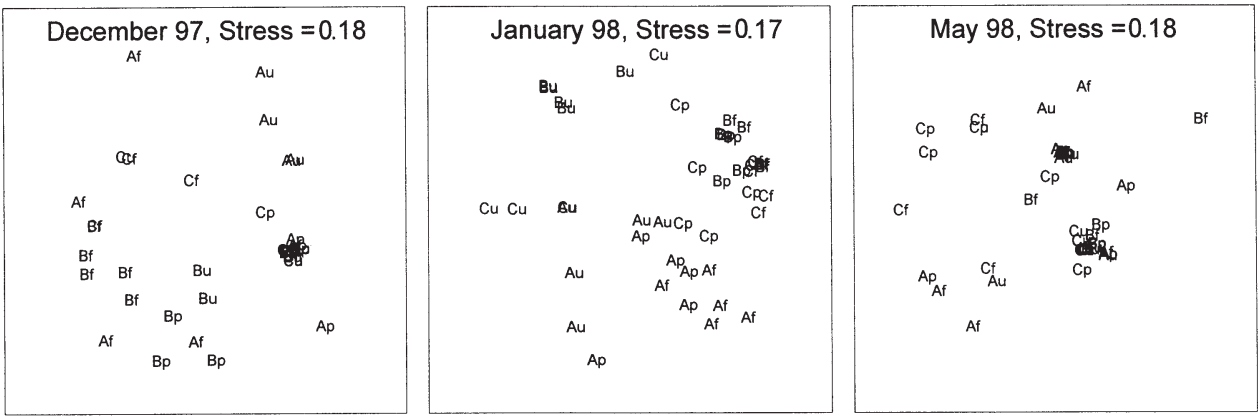

SUMMER 1998
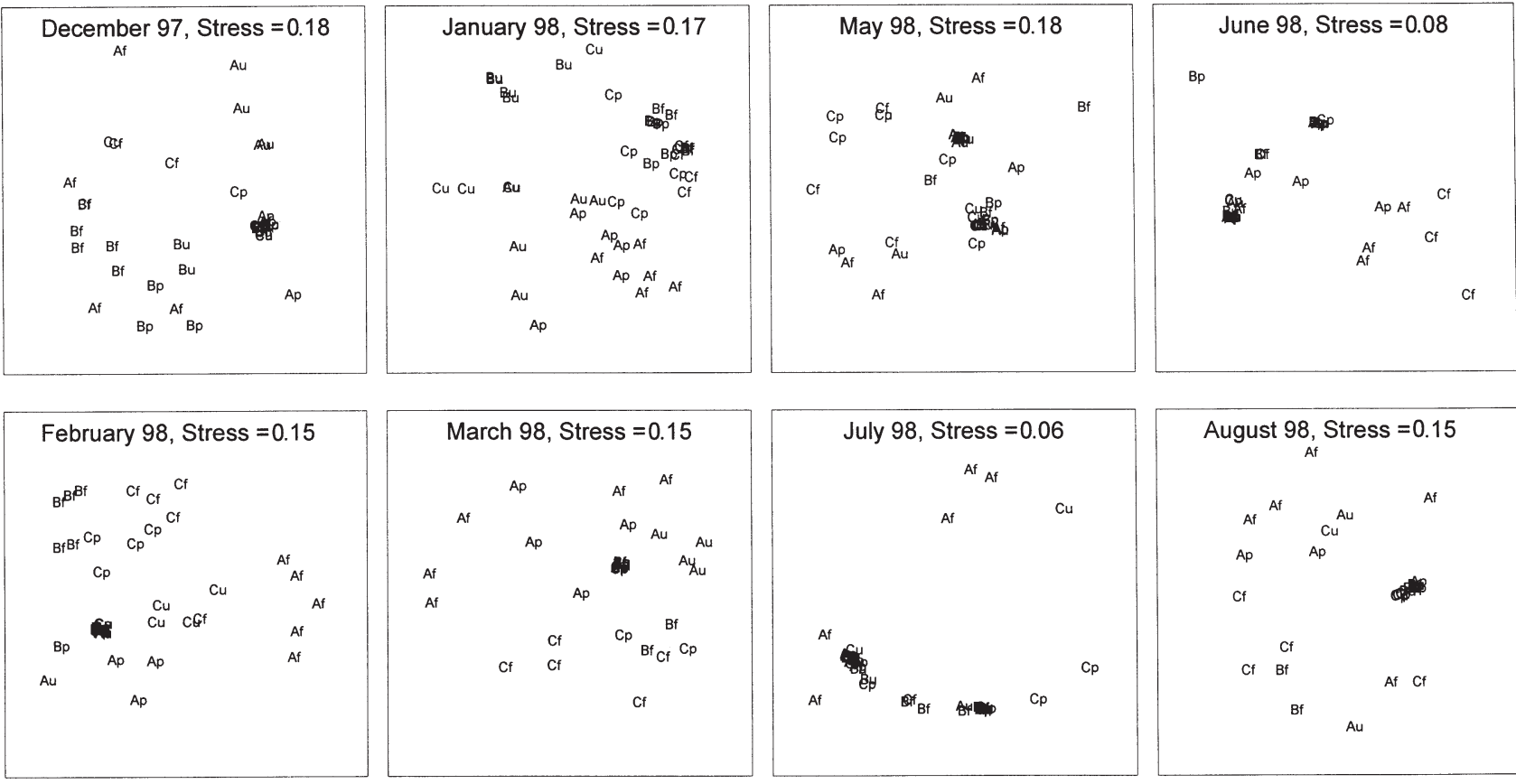

Fig. 4. nMDS plots of similarities in species recruitment for Cape d'Aguilar Sites A to C. Data represent variation between fenced (f), partially fenced (p) and unfenced (u) experimental plots $(n=5)$

The general pattern for all sites was for greater recruitment in fenced plots than in partial or unfenced plots (Fig. 1). There was not, however, a consistent pattern of variation between partially fenced and unfenced plots, as on some dates percentage cover of recruits was greater in partial plots and on others in unfenced plots (Fig. 1). nMDS plots of assemblage data showed that there were identifiable differences in assemblage structure between treatments at the different sites (Fig. 4). Groupings of similarity can be seen in winter (Fig. 4), with experimental treatments separating out from each other more clearly than site differences, e.g. distinct groups in February. These patterns, however, were not consistent among months, e.g. distinct differences in groupings of treatments and sites in January differed greatly from those in February. As would be expected, with low recruitment occurring in summer, there was little difference between treatments and sites, with groupings including all combinations of sites and treatments, and with no apparent pattern (Fig. 4) even when stress values indicated the strongest possible relationships (e.g. June and July).

Further examination of assemblage variation with 2 -factor, crossed ANOSIM showed that there were significant differences between sites in all months except June (Fig. 5), and that treatment effects across sites also varied significantly in all months, except May (Table 5, Fig. 5). There appeared to be some general
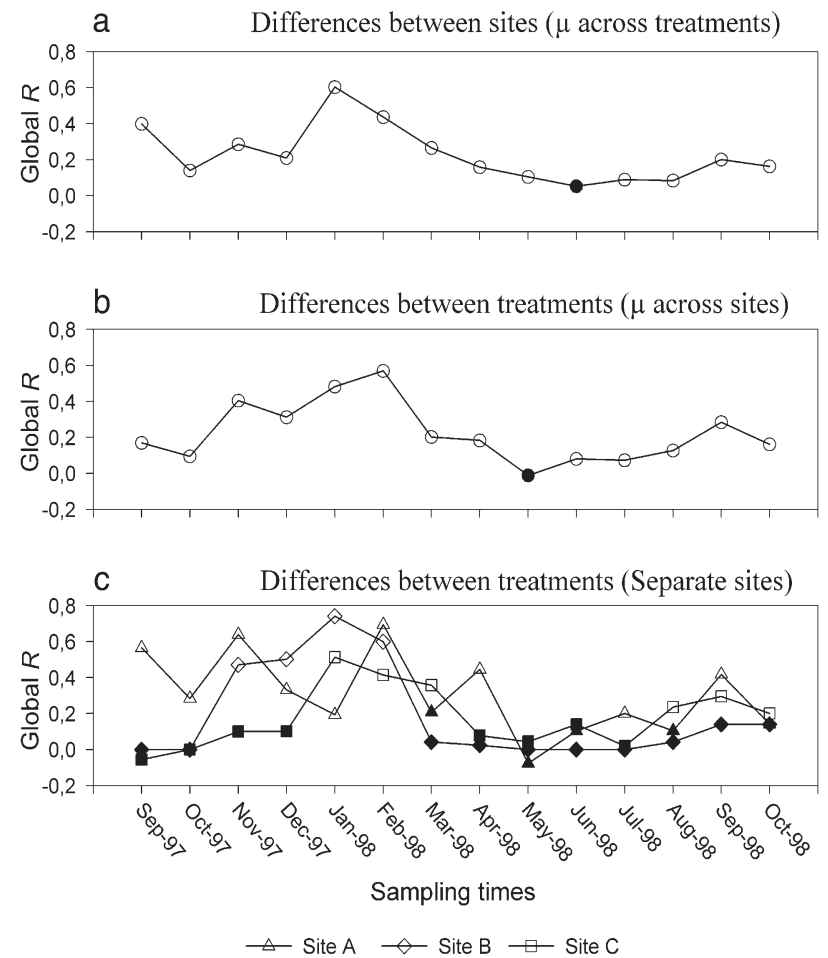

Fig. 5. Monthly variation in global $\mathrm{R}$ values for sites from 2 -factor ANOSIM (a), treatments from 2-factor ANOSIM (b) and treatments at each site from 1-factor ANOSIM (c). Open symbols represent significant differences $(p<0.05)$ 
Table 5. Summary table of R values from pairwise tests between fenced (F), partially fenced (P) and unfenced (U) plots; and between sites (A to C) from 2-factor ANOSIM on all dates. Significantly different comparisons $(p<0.05)$ are shown in bold

\begin{tabular}{|lrrrrrrr|}
\hline \multirow{2}{*}{ Month } & \multicolumn{2}{c}{ F vs P } & \multicolumn{2}{c|}{ F vs U } & P vs U & \multicolumn{2}{c|}{ A vs B A vs C B vs C } \\
\hline September & -0.013 & $\mathbf{0 . 2 6 9}$ & $\mathbf{0 . 2 3 7}$ & $\mathbf{0 . 6 6 7}$ & $\mathbf{0 . 6 3 7}$ & 0.023 \\
October & 0.083 & 0.192 & 0.008 & $\mathbf{0 . 2 1 2}$ & $\mathbf{0 . 2 1 2}$ & -0.008 \\
November & $\mathbf{0 . 5 1 4}$ & $\mathbf{0 . 5 7 3}$ & 0.123 & $\mathbf{0 . 4 8 9}$ & $\mathbf{0 . 4 2 1}$ & -0.004 \\
December & $\mathbf{0 . 3 8 7}$ & $\mathbf{0 . 4 3 8}$ & 0.133 & $\mathbf{0 . 3 0 8}$ & $\mathbf{0 . 1 6 9}$ & $\mathbf{0 . 2 2 7}$ \\
January & 0.128 & $\mathbf{0 . 8 1 3}$ & $\mathbf{0 . 5 3 3}$ & $\mathbf{0 . 8 6 4}$ & $\mathbf{0 . 5 2 7}$ & $\mathbf{0 . 4 5 1}$ \\
February & $\mathbf{0 . 7 6 5}$ & $\mathbf{0 . 7 9 9}$ & $\mathbf{0 . 2 0 2}$ & $\mathbf{0 . 3 6 3}$ & $\mathbf{0 . 5 7 0}$ & $\mathbf{0 . 4 4 2}$ \\
March & 0.130 & $\mathbf{0 . 3 7 9}$ & $\mathbf{0 . 1 1 1}$ & $\mathbf{0 . 3 3 5}$ & $\mathbf{0 . 2 9 7}$ & $\mathbf{0 . 1 7 8}$ \\
April & $\mathbf{0 . 2 5 9}$ & $\mathbf{0 . 2 7 7}$ & 0.036 & $\mathbf{0 . 1 7 6}$ & $\mathbf{0 . 2 6 8}$ & 0.050 \\
May & -0.045 & 0.023 & -0.002 & $\mathbf{0 . 1 0 7}$ & 0.106 & $\mathbf{0 . 1 2 3}$ \\
June & 0.107 & $\mathbf{0 . 1 6 0}$ & 0.000 & 0.072 & -0.008 & 0.080 \\
July & $\mathbf{0 . 1 3 3}$ & $\mathbf{0 . 1 0 0}$ & -0.016 & 0.100 & $\mathbf{0 . 1 3 3}$ & 0.033 \\
August & $\mathbf{0 . 1 5 8}$ & 0.086 & 0.011 & $\mathbf{0 . 1 5 8}$ & 0.086 & 0.011 \\
September & $\mathbf{0 . 2 7 6}$ & $\mathbf{0 . 4 8 8}$ & 0.089 & $\mathbf{0 . 3 8 3}$ & 0.116 & $\mathbf{0 . 1 4 3}$ \\
October & $\mathbf{0 . 1 8 8}$ & $\mathbf{0 . 2 6 7}$ & 0.033 & $\mathbf{0 . 1 3 8}$ & $\mathbf{0 . 1 8 6}$ & $\mathbf{0 . 1 9 9}$ \\
\hline
\end{tabular}

treatment effects from November to March (Table 5), with unfenced plots being significantly different from fenced plots at these times, and more variable relationships between fenced and partially fenced plots. Significant differences were also generally found between sites throughout the study (Table 5). Analysis with 1-factor ANOSIM on each sampling date showed that significant differences in assemblage structure between treatments varied between sites (Fig. 5). The expected difference, if the partial fences were a successful control for fence effects and grazer exclusion had an effect, would have been for no difference between partial and unfenced plots, but a significant difference from fenced plots. While this occurred in some cases during winter (e.g. Site B in December and February as well as Site A in February: Table 6), it was not consistent across sites or dates, with significant differences between treatments being found $67 \%$ of times between fenced and unfenced treatments, and $42 \%$ of times for differences between the other treatments (Table 6). Such differences were less apparent during summer, with significant differences between fenced and unfenced treatments in only $8 \%$ of cases, between fenced and partially fenced treatments in $17 \%$ of cases, and no differences between partially fenced and unfenced plots (Table 7).

\section{DISCUSSION}

\section{Spatio-temporal variation in recruitment patterns}

The present study highlights the fact that recruitment of sessile invertebrates and algae is highly variable within semi-exposed shores in Hong Kong. At any point
Table 6. Summary table of $\mathrm{R}$ values from pairwise tests between fenced $(\mathrm{F})$, partially fenced $(\mathrm{P})$ and unfenced (U) plots from 1 -factor ANOSIM on 4 dates in winter. Significantly different comparisons $(\mathrm{p}<0.05)$ are shown in bold

\begin{tabular}{|lcrrr|}
\hline Month & Site & F vs P & F vs U & P vs U \\
\hline December & A & $\mathbf{0 . 3 7 2}$ & 0.302 & $\mathbf{0 . 3 7 2}$ \\
& B & $\mathbf{0 . 5 2 8}$ & $\mathbf{0 . 9 5 2}$ & 0.028 \\
January & C & 0.260 & 0.060 & 0.000 \\
& A & 0.008 & $\mathbf{0 . 5 1 2}$ & 0.066 \\
& B & 0.224 & $\mathbf{1 . 0 0 0}$ & $\mathbf{1 . 0 0 0}$ \\
February & C & 0.152 & $\mathbf{0 . 9 2 8}$ & $\mathbf{0 . 5 3 2}$ \\
& A & $\mathbf{0 . 9 7 6}$ & $\mathbf{1 . 0 0 0}$ & 0.064 \\
& B & $\mathbf{1 . 0 0 0}$ & $\mathbf{1 . 0 0 0}$ & 0.000 \\
March & C & $\mathbf{0 . 3 2 0}$ & $\mathbf{0 . 3 9 6}$ & $\mathbf{0 . 5 4 2}$ \\
& A & -0.040 & 0.346 & $\mathbf{0 . 3 0 2}$ \\
& B & 0.070 & 0.070 & 0.000 \\
& C & 0.360 & $\mathbf{0 . 7 2 0}$ & 0.030 \\
\hline
\end{tabular}

Table 7. Summary table of $\mathrm{R}$ values from pairwise tests between fenced $(\mathrm{F})$, partially fenced $(\mathrm{P})$ and unfenced $(\mathrm{U})$ plots from 1-factor, ANOSIM on 4 dates in summer. Significantly different comparisons $(p<0.05)$ are shown in bold

\begin{tabular}{|c|c|c|c|c|}
\hline Month & Site & F vs $P$ & F vs U & P vs U \\
\hline \multirow[t]{3}{*}{ May } & A & -0.124 & -0.008 & -0.092 \\
\hline & B & 0.000 & 0.000 & 0.000 \\
\hline & $\mathrm{C}$ & -0.012 & 0.078 & 0.086 \\
\hline \multirow[t]{3}{*}{ June } & A & 0.082 & 0.240 & 0.000 \\
\hline & B & 0.000 & 0.000 & 0.000 \\
\hline & $\mathrm{C}$ & 0.240 & 0.240 & 0.000 \\
\hline \multirow[t]{3}{*}{ July } & A & 0.300 & 0.300 & 0.000 \\
\hline & B & 0.000 & 0.000 & 0.000 \\
\hline & $\mathrm{C}$ & 0.100 & 0.000 & -0.048 \\
\hline \multirow[t]{3}{*}{ August } & A & 0.166 & 0.218 & -0.100 \\
\hline & B & 0.070 & 0.070 & 0.000 \\
\hline & $\mathrm{C}$ & 0.380 & 0.340 & 0.000 \\
\hline
\end{tabular}

in time, recruitment to areas of the shore within relatively short distances (i.e. 10s of metres) of each other may differ in both the species recruiting and the density of new recruits. This patchy recruitment can also be seen at smaller spatial scales (metres), with highly variable distributions of species between plots within the same site. Such spatially and temporally patchy recruitment also occurs on shores in the Mediterranean, where differences between experimental blocks within 100 s of metres of each other were suggested to be primarily due to variation in the availability of propagules (Benedetti-Cecchi \& Cinelli 1993). Benedetti-Cecchi \& Cinelli also found temporal variation in the magnitude of colonisation, with greater cover during winter than summer, whereas in the present study the actual species colonising plots also varied throughout the year. 
Recruitment of organisms on intertidal rocky shores world-wide is known to be patchy both in space and time (Dayton 1973, Sousa 1984, Menge 1991), primarily due to disturbance events, variation in grazing intensity, and general patterns of recruitment and succession. Such variation in recruitment can also be seen elsewhere on tropical rocky shores. In Panamá, for example, a recent study found considerable spatial and temporal variation in recruitment in experimentally cleared plots, with few species recruiting throughout the year, both between and within shores (Camus \& Lagos 1996). In the present study, recruitment was patchy within a predictable seasonal time frame (i.e. winter and summer), which can be viewed as another, temporal, scale of variation in the Hong Kong intertidal.

Differences in plots throughout the year may be due mainly to variation in the availability of recruits rather than the influence of grazers, although it should be remembered that organisms recruiting in summer are those that are able to survive the harsh physical conditions at this time of year. If physical stress is reduced, for example, by shading or spraying the shore with water, more species are able to survive (Buschmann 1990, Williams 1994, Kaehler \& Williams 1998). Patterns in the present study may, therefore, indicate those species which are able to recruit and survive at this time rather than the total potential recruits available in the water column (Connell 1985), as on the shore studied some algae not found on open rock surfaces were seen in shaded crevices where there may be reduced levels of physical stress (Williams 1994).

As with other studies (Benedetti-Cecchi \& Cinelli 1993, Kaehler \& Williams 1998), species recruiting to cleared areas of rock are usually found elsewhere on undisturbed stretches of the shore, although there are exceptions such as the thin, mixed turf of green sporelings that are only rarely found on other areas of the shore (Kaehler \& Williams 1998). Such fugitive species, which are found during the initial stages of succession on many shores (Murray \& Littler 1978, Niell \& Varela 1984), are often replaced with time by other species. As plots in the present study were cleared on a monthly basis, no conclusion can be drawn as to how succession might proceed, nor how the species complements might have changed over a longer time period. Previous studies (Williams 1993b, Williams et al. 2000), however, suggest that while successional changes will occur over the winter, these changes are largely erased later in the year due to the summer die-off associated with high levels of physical stress.

\section{Spatio-temporal variation in grazer exclusion}

There was no underlying pattern from the exclusion of molluscs to suggest consistent treatment effects, e.g. one might expect grazing to have an effect in winter and not summer, or in areas with higher overall grazer densities (Site A). Whilst it appears that exclusions (fences) lead to increased levels of colonisation compared with open areas, lack of clear differences between exclusion and control treatments (partial fence and unfenced plots) make it difficult to resolve treatment effects. The increased colonisation may have been due to a decrease in grazing because of the exclusion of herbivorous molluscs, or an experimental artefact due to the partial fence, such as shading or propagule entrapment (see discussion by Hall et al. 1990). Previous studies on Hong Kong shores have shown that herbivore exclusion has an effect low on the shore, year-round, but only at the level examined (mid-shore, 1.5 m CD) during winter (Williams 1993b). At this level, such differences between treatments (Williams 1993a, b, 1994) have, however, only become apparent after a longer period of time (differences in algae seen after $>170 \mathrm{~d}$, no chlorophyll a differences after $30 \mathrm{~d}$ : see Williams 1993b) than the month that plots were maintained in the present study.

Whilst the present study found differences in percentage cover between treatments throughout the 14 mo of the study, the effect of grazer exclusion varied both with time and between sites within a shore. While total fences successfully excluded molluscan grazers and the partially fenced and unfenced plots contained grazers during surveys at all 3 sites at low tide, observations when plots were immersed revealed that the herbivorous fish Entomacrodus stellifer and the crab Grapsus albolineatus gained access to, and appeared to feed on, erect algae and the turf of green sporelings during both winter and summer. Whilst the timing of such observations was irregular, it raises the question of how successful these exclusion designs are on all Hong Kong shores and whether roofed cages would be more effective. Previous exclusion experiments on local shores (Williams 1993b, Kaehler 1996) found that fenced plots without roofs were able to promote vigorous algal growth, in contrast to experiments elsewhere in the tropics, e.g. Panamá (Menge et al. 1985), where growth was found only in roofed cages which excluded crabs and fishes. While large densities of fishes and crabs do not appear to occur in Hong Kong (Williams 1994), and results from past studies suggest that they do not play as important a role on Hong Kong shores (Williams 1993b, 1994, Kaehler 1996), there may be sufficient densities, on some shores, to affect recruitment patterns. Also, while low-tide surveys found significant differences between grazer densities at the different sites, there does not appear to be any relationship between this and percentage algal cover or chlorophyll $a$ concentration in plots of different treatments. This suggests that transect counts may not be a good indicator of 
the actual grazing pressure exerted at the sites, or that between-site differences in grazing pressure were not of a sufficient magnitude to produce such variation.

\section{Local versus non-local processes}

The abundance of species in an assemblage may be increased by disturbance events if free space is limiting and created when species propagules are present and available for recruitment (Kim \& DeWreede 1996). The availability of propagules is, therefore, extremely important, as the creation of a patch at a certain time of the year may result in a different assemblage to that produced at a different time (Jara \& Moreno 1984, Menge et al. 1993). The intensity and timing of propagule availability (Underwood \& Fairweather 1989) are, therefore, important in influencing the eventual structure of intertidal communities, as recruitment itself is known to be spatially and temporally variable at a variety of scales (Underwood \& Denley 1984, Menge \& Sutherland 1987, Roughgarden et al. 1987, Menge 1991, Lively et al. 1993).

In addition to the creation of free space, the processes involved in settlement and recruitment (for definitions see Connell 1985) are likely to be ultimately responsible for the patchy distribution of organisms elsewhere on intertidal shores (Raimondi 1990). The factors responsible for settlement and recruitment vary between species, as they may have different requirements and respond to specific cues such as surface chemistry (Crisp 1974) and rock type (Raimondi 1988). Resident species can also have an effect, as factors such as grazing and bulldozing (e.g. Denley \& Underwood 1979) are in some cases partly responsible for variation in recruitment intensity (Niell \& Varela 1984). All of these factors combined together with recruit survival (Connell 1985), patch size (Sousa 1984), season (Hoffmann \& Ugarte 1985, Kaehler \& Williams 1997) and tidal characteristics (Shanks 1986) affect recruitment and the resulting assemblage structure.

Although recruitment patterns varied between different treatments and sites, there was no evidence to suggest that variation in grazing pressure within the shore examined at Cape d'Aguilar consistently, or predictably, affected sessile species recruitment patterns. While grazing may result in decreased cover of sessile invertebrates and algae, it does not play as important a role as large-scale, non-local processes such as recruitment and fluctuations in levels of physical (i.e. thermal and desiccation) stress.

In Hong Kong, while the local process of grazing shapes assemblage structure to a certain extent, it is secondary in importance to non-local processes. Recruit availability/supply and the large fluctuations in physical stress that occur seasonally with the onset of summer appear to be primarily responsible for the patterns of change observed in the assemblage structure on Hong Kong semi-exposed tropical shores.

Acknowledgements. Many thanks to L. Benedetti-Cecchi for statistical advice, G. Blackmore and S. Nicholson for help with maintaining the experiment, and the H.K.U. rocky shore ecology group for critical comments on the manuscript. This work was conducted in partial fulfilment of the requirements for a $\mathrm{PhD}$ by N.H. and supported by a part-time demonstratorship at The University of Hong Kong. Permission to work at the Cape d'Aguilar Marine Reserve was kindly granted by AFCD, Hong Kong Government.

\section{LITERATURE CITED}

Barry JP, Baxter CH, Sagarin RD, Gilma SE (1995) Climaterelated, long-term faunal changes in a California rocky intertidal community. Science 267:672-675

Benedetti-Cecchi L, Cinelli F (1993) Early patterns of algal succession in a midlittoral community of the Mediterranean Sea: a multifactorial experiment. J Exp Mar Biol Ecol 169:15-31

Buschmann AH (1990) The role of herbivory and desiccation on early successional patterns of intertidal macroalgae in southern Chile. J Exp Mar Biol Ecol 139:221-230

Camus PA, Lagos NA (1996) Variación espacio-temporal del reclutamiento en ensambles intermareales sésiles del norte de Chile. Rev Chil Hist Nat 69:193-204

Clarke KR (1993) Non-parametric multivariate analyses of changes in community structure. Aust J Ecol 18:117-143

Connell JH (1985) The consequences of variation in initial settlement vs. post-settlement mortality in rocky intertidal communities. J Exp Mar Biol Ecol 93:11-45

Crisp DJ (1974) Factors influencing the settlement of marine invertebrate larvae. In: Grant PT, Mackie AM (eds) Chemoreception in marine organisms. Academic Press, London, p 177-265

Dayton PK (1973) Dispersion, dispersal, and persistence of the annual intertidal alga, Postelsia palmaeformis Ruprecht. Ecology 54:432-438

Denley EJ, Underwood AJ (1979) Experiments on factors influencing settlement, survival and growth of two species of barnacles in New South Wales. J Exp Mar Biol Ecol 36: 269-293

Gaines S, Roughgarden J (1985) Larval settlement rate: a leading determinant of structure in an ecological community of the marine intertidal zone. Proc Natl Acad Sci USA 82:3707-3711

Hall SJ, Raffaelli D, Turrell WR (1990) Predator-caging experiments in marine systems: a reexamination of their value. Am Nat 136:657-672

Hawkins SJ, Hartnoll RG (1982) Settlement patterns of Semibalanus balanoides (L.) in the Isle of Man (1977-1981). J Exp Mar Biol Ecol 62:271-283

Hawkins SJ, Hartnoll RG (1983) Grazing of intertidal algae by marine invertebrates. Oceanogr Mar Biol Annu Rev 21: 195-282

Hodgkiss IJ (1984) Seasonal patterns of intertidal algal distribution in Hong Kong. Asian Mar Biol 1:49-57

Hoffmann AJ, Ugarte R (1985) The arrival of propagules of marine macroalgae in the intertidal zone. J Exp Mar Biol Ecol 92:83-95 
Jara HF, Moreno CA (1984) Herbivory and structure in a midlittoral rocky community in Southern Chile. Ecology 65:28-38

Jernakoff P (1985) Temporal and small-scale spatial variability of algal abundance on an intertidal rocky shore. Bot Mar 28:145-154

Johnson MS, Black R (1982) Chaotic genetic patchiness in an intertidal limpet, Siphonaria sp. Mar Biol 70:157-164

Johnson MS, Black R (1984) Pattern beneath the chaos: the effect of recruitment on genetic patchiness in an intertidal limpet (Siphonaria jeanae). Evolution 38:1371-1383

Johnson MS, Black R (1998) Effects of isolation by distance and geographical discontinuity on genetic subdivision of Littoraria cingulata. Mar Biol 132:295-303

Kaehler S (1996) Causes and consequences of the spatial and temporal distribution of encrusting algae on tropical rocky shores. PhD thesis, University of Hong Kong

Kaehler S, Williams GA (1996) Distribution of algae on tropical rocky shores: spatial and temporal patterns of noncoralline encrusting algae in Hong Kong. Mar Biol 125: $177-187$

Kaehler S, Williams GA (1997) Do factors influencing recruitment ultimately determine the distribution and abundance of encrusting algae on seasonal tropical shores? Mar Ecol Prog Ser 156:87-96

Kaehler S, Williams GA (1998) Early development of algal assemblages under different regimes of physical and biotic factors on a seasonal tropical rocky shore. Mar Ecol Prog Ser 172:61-71

Kim JH, DeWreede RE (1996) Effects of size and season of disturbance on algal patch recovery in a rocky intertidal community. Mar Ecol Prog Ser 133:217-228

Lawson GW (1957) Seasonal variation of intertidal zonation on the coast of Ghana in relation to tidal factors. J Ecol 45: 831-860

Lively CM, Raimondi PT, Delph LF (1993) Intertidal community structure: space-time interactions in the Northern Gulf of California. Ecology 74:162-173

Lubchenco J, Menge BA (1978) Community development and persistence in a low rocky intertidal zone. Ecol Monogr 48: 67-94

Machado SSKR, Chapman ARO, Coutinho R (1992) Patch structure in a tropical rocky shore community in Brazil: a mosaic of successional states? Ophelia 35:187-195

Menge BA (1991) Relative importance of recruitment and other causes of variation in rocky intertidal community structure. J Exp Mar Biol Ecol 146:69-100

Menge BA, Sutherland JP (1987) Community regulation: variation in disturbance, competition, and predation in relation to environmental stress and recruitment. Am Nat 130: 730-757

Menge BA, Lubchenco J, Ashkenas LR (1985) Diversity, heterogeneity and consumer pressure in a tropical rocky intertidal community. Oecologia 65:394-405

Menge BA, Farrell TM, Olson AM, Tamelen PV, Turner T (1993) Algal recruitment and the maintenance of a plant mosaic in the low intertidal region on the Oregon coast. J Exp Mar Biol Ecol 170:91-116

Morrisey DJ, Howitt L, Underwood AJ, Stark JS (1992) Spatial variation in soft-sediment benthos. Mar Ecol Prog Ser 81: 197-204

Murray SN, Littler MM (1978) Patterns of algal succession in a perturbated marine intertidal community. J Phycol 14: 506-512

Nagarkar S, Williams GA (1997) Comparative techniques to quantify cyanobacteria dominated epilithic biofilms on tropical rocky shores. Mar Ecol Prog Ser 154:281-291
Niell FX, Varela M (1984) Initial colonization stages on rocky coastal substrates. PSZN I: Mar Ecol 5:45-56

Paine RT, Levin SA (1981) Intertidal landscapes: disturbance and the dynamics of pattern. Ecol Monogr 51:145-178

Pierron RP, Huang YC (1926) Animal succession on denuded rocks. Publ Puget Sound Mar Biol Stn 5:149-157

Raimondi PT (1988) Rock type affects settlement, recruitment, and zonation of the barnacle Chthamalus anisopoma Pilsbury. J Exp Mar Biol Ecol 123:253-267

Raimondi PT (1990) Patterns, mechanisms, consequences of variability in settlement and recruitment of an intertidal barnacle. Ecol Monogr 60:283-309

Roughgarden J, Gaines SD, Pacala SW (1987) Supply side ecology: the role of physical transport processes. In: Gee JHR, Giller PS (eds) Organization of communities, past and present. Blackwell Scientific Publications, Oxford, p 491-514

Shanks AL (1986) Tidal periodicity in the daily settlement of intertidal barnacle larvae and an hypothesized mechanism for the cross-shelf transport of cyprids. Biol Bull 170: $429-440$

Sousa WP (1984) Intertidal mosaics: patch size, propagule availability, and spatially variable patterns of succession. Ecology 65:1918-1935

Sutherland JP (1987) Recruitment limitation in a tropical intertidal barnacle: Tetraclita panamensis (Pilsbury) on the Pacific coast of Costa Rica. J Exp Mar Biol Ecol 113:267-282

Sutherland JP, Ortega S (1986) Competition conditional on recruitment and temporary escape from predators on a tropical rocky shore. J Exp Mar Biol Ecol 95:155-166

Underwood AJ (1993) The mechanisms of spatially replicated sampling programmes to detect environmental impacts in a variable world. Aust J Ecol 18:99-116

Underwood AJ (1994) Spatial and temporal problems with monitoring. In: Calow P, Petts GE (eds) The rivers handbook, Vol 2. Blackwell Scientific Publications, Oxford, p 101-123

Underwood AJ (1997) Experiments in ecology. Cambridge University Press, Cambridge

Underwood AJ, Denley EJ (1984) Paradigms, explanations, and generalisations in models for the structure of intertidal communities on rocky shores. In: Strong DR, Simberlopf D, Abele LG, Thistle AB (eds) Ecological communities: conceptual issues and the evidence. Princeton University Press, Princeton, p 151-180

Underwood AJ, Fairweather PG (1989) Supply-side ecology and benthic marine assemblages. Trends Ecol Evol 4:16-20

Underwood AJ, Jernakoff P (1984) The effects of tidal height, wave-exposure, seasonality and rock-pools on grazing and the distribution of intertidal macroalgae in New South Wales. J Exp Mar Biol Ecol 75:71-96

Underwood AJ, Petraitis PS (1993) Structure of intertidal assemblages in different locations: how can local processes be compared? In: Ricklefs RE, Schluter D (eds) Species diversity in ecological communities. Historical and geographical perspectives. The University of Chicago Press, Chicago, p 39-51

Walters LJ, Hadfield MG, Smith CM (1996) Waterborne chemical compounds in tropical macroalgae: positive and negative cues for larval settlement. Mar Biol 126:383-393

Williams GA (1993a) The relationship between herbivorous molluscs and algae on moderately exposed Hong Kong shores. In: Morton B (ed) The marine biology of the South China Sea. Proceedings of the First International Conference on the Marine Biology of Hong Kong and the South China Sea. Hong Kong University Press, Hong Kong, p 459-469

Williams GA (1993b) Seasonal variation in algal species rich- 
ness and abundance in the presence of molluscan herbivores on a tropical rocky shore. J Exp Mar Biol Ecol 167: 261-275

Williams GA (1994) The relationship between shade and molluscan grazing in structuring communities on a moder-

Editorial responsibility: Otto Kinne (Editor),

Oldendorf/Luhe, Germany ately-exposed tropical rocky shore. J Exp Mar Biol Ecol 178:79-95

Williams GA, Davies MS, Nagarkar S (2000) Primary succession on a tropical rocky shore: impacts of spatial variation in herbivory. Mar Ecol Prog Ser 203:81-94

Submitted: June 2, 2000; Accepted: October 5, 2000

Proofs received from author(s): May 18, 2001 